\title{
Aktifitas Kitosan-Glukosa Sebagai Pengawet Ikan Bandeng Duri Lunak
}

\author{
Oftiana Irayanti Wardani ${ }^{*}$, R. Arizal Firmansyah ${ }^{2}$, Siti Muhlishoh Setyawati ${ }^{3}$ \\ 1Lembaga Pengkajian Pangan, Obat-obatan dan Kosmetika MUI Jawa Tengah, Indonesia \\ 2Program Studi Kimia Fakultas Sains dan Teknologi Universitas Islam Negeri Walisongo \\ Semarang, Indonesia \\ 3 Program Studi Biologi Fakultas Sains dan Teknologi Universitas Islam Negeri Walisongo \\ Semarang, Indonesia \\ *Email: oftianawardani@yahoo.com
}

\begin{abstract}
Abstrak
Modifikasi Kitosan dengan Glukosa mampu memperbaiki kemampuan kitosan dalam mengawetkan makanan. Kitosan-Glukosa yang diaplikasikan pada ikan bandeng duri lunak dengan cara pelapisan menghasilkan adanya perbedaan kandungan protein sebesar 0,0045\%, 0,0048\%, dan 0,072\%. Sedangkan perbedaan kandungan mikroba sebesar $4,05 \times 10^{4} ; 7 \times 10^{4}$; dan $1,37 \times 10^{6}$. Pengukuran tersebut dilakukan di hari ke 1, 3, dan 5 pada kontrol ikan yang tidak mengalami pelapisan dengan ikan yang mengalami pelapisan. Hasil uji organoleptik dengan skala nilai 1-4 pada tampilan, aroma, warna dan rasa pada hari ke 5 menunjukkan bahwa nilai ikan yang mengalami pelapisan lebih tinggi dari pada yang tidak mengalami pelapisan. Uji IR menunjukkan tidak ada gugus baru terbentuk antara kitosanglukosa.
\end{abstract}

Kata kunci : kitosan-glukosa; pengawet; bandeng duri lunak

\section{Pendahuluan}

Kitosan merupakan biopolimer alam turunan kitin yang jumlahnya sangat melimpah setelah selulosa (Qin Wang, 2013). Kitosan banyak diisolasi dari limbah kulit udang, rajungan, atau kepiting melalui proses deasetilasi kitin. Sifat kitosan yang mempunyai gugus amina bebas bermuatan positif dapat berikatan dengan muatan negatif pada dinding sel bakteri. Hal tersebut membuat kitosan banyak dimanfaatkan diberbagai bidang khususnya untuk pengawetan (Sally Ratna, 2013).

Pengujian laboratorium memperlihatkan bahwa efektifitas penggunaan kitosan sebagai anti bakteri dan anti oksidan masih memiliki kelemahan (Rao et all, 2005). Bahkan dalam berbagai aplikasi kitosan cenderung rapuh dan mudah pecah (Selly Ratna, 2013). Beberapa riset telah mengembangkan metode untuk 
memperbaiki sifat kitosan dengan modifikasi bahan kimia atau enzim. Kitosan-lysosum misalnya, telah dilapokan memiliki sifat emulsifier yang lebih baik daripada kitosan saja (Song Bab et all, 2002).

Penambahan glukosa 1\%, didalam kitosan $1 \%$ dan asam asetat $1 \%$ telah dilaporkan memiliki kemampuan melawan bakteri perusak makanan dan bakteri patogen serta memiliki anti oksidan (Kanatt et all, 2008). Metode yang dilakukan sebelumnya yaitu dengan cara sterilisasi glukosa, kitosan, dan asam asetat yang disebut Chitosan Glukose Compleks (CGC). Proses sterilisasi mengubah warna larutan glukosa, kitosan, dan asam asetat menjadi kecoklatan yang disebut dengan reaksi maillard.

Reaksi maillard merupakan reaksi non enzimatis yang melibatkan interaksi antara gula pereduksi dan asam amino atau protein dengan menghasilkan produk yang berwarna kecoklatan. Pembentukan produk maillard ini ditandai dengan adanya aroma, rasa dan warna kecoklatan yang sangat potensial untuk antioksidan pada produk makanan (Phisut et all, 2013).

Penelitian yang telah dilakukan difokuskan kepada sifat dari modifikasi kitosan-glukosa tanpa pengujian secara langsung pada bahan makanan. Telah disebutkan bahwa kitosan-glukosa sangat potensial untuk pengawet dibidang makanan sehingga penelitian ini dimaksudkan untuk melihat aktivitas kitosan-glukosa yang diaplikasikan pada ikan bandeng duri lunak malalui proses pelapisan. Hal yang diamati meliputi sifat kimia kitosan-glukosa serta pengaruhnya kepada produk makanan yang meliputi kandungan protein, kandungan mikrobia dan uji organoleptik.

\section{Metode Penelitian}

Alat dan Bahan

Alat yang digunakan adalah neraca Scout pro SPS $202 \mathrm{~F}$, gelas ukur pyrex, labu ukur pyrex, pipet volume pyrex, gelas piala pyrex, Erlenmeyer pyrex, stirrer Yanaco JBZ-14H, dan autoklaf All American 25X, pipet tetes, botol sampel, FT-IR 96772, spatula, corong, tabung sentrifuse, sentrifuse Scilogex DM0412, pipet ukur pyrex, bola hisap, spektro visible Thermo scientific genesis 20, cawan petri pyrex, lampu spirtus, oven Yenaco, koloni konter Funke gerber, lemari pendingin, dan kotak enkas.

Bahan yang digunakan adalah Kitosan food grade (didapat dari PT. Biotech Surindo), glukosa, asam asetat food grade (Merk Dixi dari PT. Sidola), aquades, bovin serum albumin, biuret, amonium sulfat, buffer asetat pH 5, kentang, agar plane (merk swallow), sukrosa.

Prosedur Kerja

Penelitian yang dilakukan beberapa tahap yaitu dimulai dari modifikasi Kitosan-Glukosa, Karakterisasi Kitosan-Glukosa dan aplikasi Kitosan-Glukosa. Setelah diaplikasikan ke produk makanan, selanjutnya dilakukan beberapa uji yaitu uji kandungan protein, uji kandungan mikrobia, dan uji organoleptik.

Modifikasi Kitosan-Glukosa. 5 gram kitosan dilarutkan dalam larutan asam asetat food grade $1 \%$ sebanyak $250 \mathrm{ml}$. Selanjutnya ditambah 5 gram glukosa dan diaduk kembali hingga homogen. Campuran tersebut ditambah aquades hingga volume $500 \mathrm{ml}$. Campuran kitosan-glukosa kemudian dipanaskan selama 15 menit dengan suhu $121^{\circ} \mathrm{C}$ di dalam autoklaf. (Kanatt, 2007).

\section{Karakterisasi}

Kitosan-Glukosa.

Campuran kitosan-glukosa setelah melalui proses pemanasan didalam autoklaf diambil $5 \mathrm{ml}$ untuk dilakukan uji spektrofotometri infra merah (IR). Pengujian spektrometri infra merah juga dilakukan pada kitosan yang dilarutkan dalam asam asetat serta glukosa murni sebagai pembanding. 
Aplikasi Kitosan-Glukosa. Ikan yang telah dibersihkan direndam dalam campuran kitosan glukosa selama 10 menit untuk selanjutnya mengalami proses pelunakan ikan. Setelah dipresto ikan didinginkan dan dikemas dalam keadaan vakum. Ikan yang telah dikemas didiamkan selama 5 hari untuk dilihat keawetannya. Pengambilan sampel uji dilakukan pada hari ke 1, 3, dan 5

Uji Protein Ikan. 10 gram daging ikan dihaluskan. Daging ikan yang halus dilarutkan dalam $10 \mathrm{ml}$ aquades lalu disaring. Residu selanjutnya dilarutkan dengan buffer asetat pH 5 hingga volume $10 \mathrm{ml}$. pelarutan dilakukan didalam tabung sentrifuse. Sebelum disentrifuse larutan ditambah amoium sulfat sebanyak 2 gram dan digojok hingga larut. Proses sentrifuse dilakukan selama 10 menit dengan kecepatan 2200 rpm. Supernatan yang terbentuk diambil dan dilarutkan dalam buffer asetat pH 5 hingga $10 \mathrm{ml}$. Setelah preparasi sampel selanjutnya sampel diambil $2 \mathrm{ml}$ dan dilarutkan dalam $8 \mathrm{ml}$ larutan biuret. Campuran didiamkan hingga 10 menit dan selanjutnya diukur adsorbansinya dengan spektrofotometri visible (Abdul Rohmn, 2007).

Uji Kandungan Mikroba. Media untuk uji mikrobiologi adalah PDA (Potato Dextro Agar). Media ini dibuat dengan bahan baku kentang segar yang didapat dari pasar Jrakah Semarang. Kentang dicuci bersih dan ditimbang sebanyak 250 gram lalu dihaluskan.Kentang halus ditambah dengan $500 \mathrm{ml}$ aquades dan beaker ditutup dengan alumunium foil untuk persiapan proses pemanasan. Pemanasan menggunakan waterbath selama 30 menit. Filtrat diambil $100 \mathrm{ml}$ lalu ditambah 2 gram sukrosa dan 2 gram agar. Campuran dimasak dengan api kecil sebentar. Setelah selesai campuran disterilisasi dengan menggunakan autoklaf selama 15 menit.

Uji Organoleptik. Uji organoleptik dilakukan oleh 30 panelis tidak terlatih. Pengujian organoleptik dilakukan dengan mengisi formulir yang telah diberikan kepada panelis. Hal yang perlu dinilai oleh panelis adalah tampilan fisik produk, bau, warna, dan rasa.

\section{Hasil Penelitian dan Pembahasan}

Kitosan-Glukosa.Secara tampilan warna terdapat perbedaan antara campuran kitosanglukosa yang dipanaskan dengan sebelum dipanaskan. Jika dibandingkan, campuran kitosanglukosayang dipanaskan membentuk warna yang lebih coklat dan aroma yang lebih harum dibanding sebelum dipanaskan. (gambar 1 )
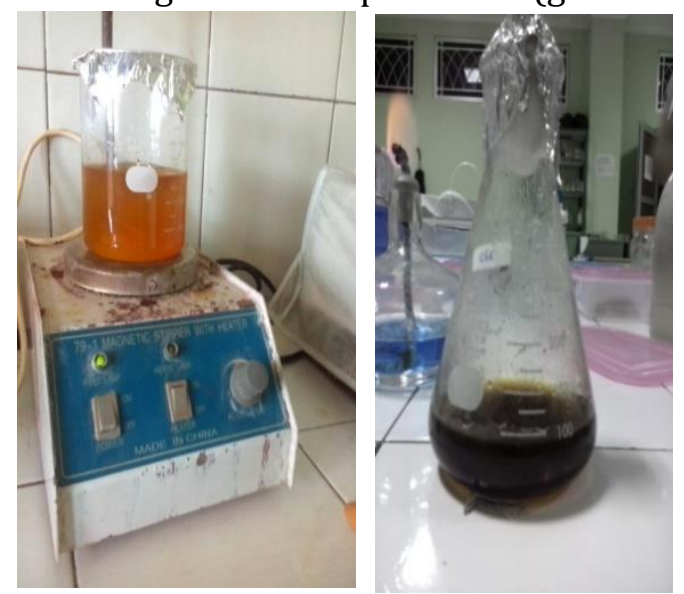

Gambar 1. Perbedaan warna larutan KitosanGlukosa sebelum dan setelah pemanasan

Karakterisasi dengan IR. Spektra IR Kitosan murni dan Kitosan-Glukosa dapat dilihat pada gambar 2 .

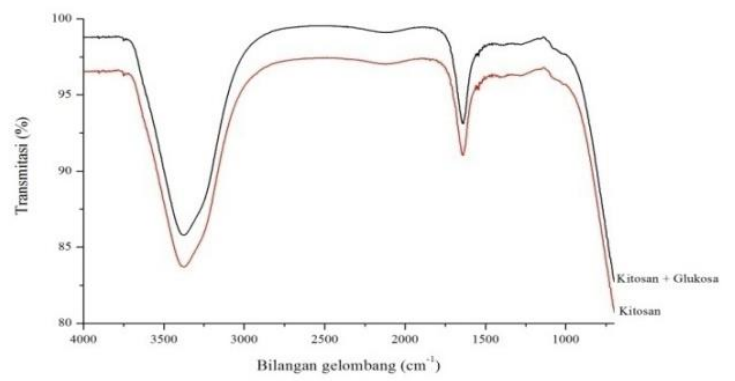

Gambar 2. Spektra Kitosan-Glukosa (hitam) dan Spektra kitosan (merah)

Uji Organoleptik. Pengujian organoleptik dilakukan oleh 30 panelis tidak terlatih. Panelis memberikan nilai dengan range 1-4 (Gambar 3). Kode A merupakan kode untuk ikan bandeng yang tidak direndam campuran kitosan-glukosa sedangkan kode B merupakan ikan yang telah mengalami perendaman. 


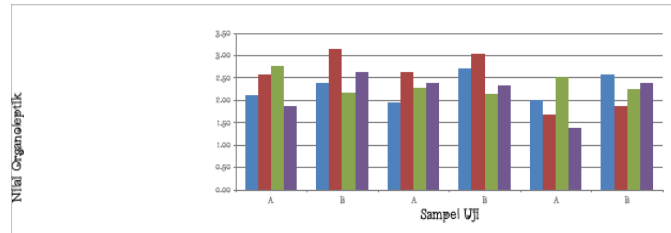

Gambar 3. Pengujian organoleptik

Uji Protein. Penentuan protein ikan dilakukan dengan pengulangan dua kali (duplo). Berikut hasil pengujian kadar protein sampel ikan disajikan dalam(gambar 3).

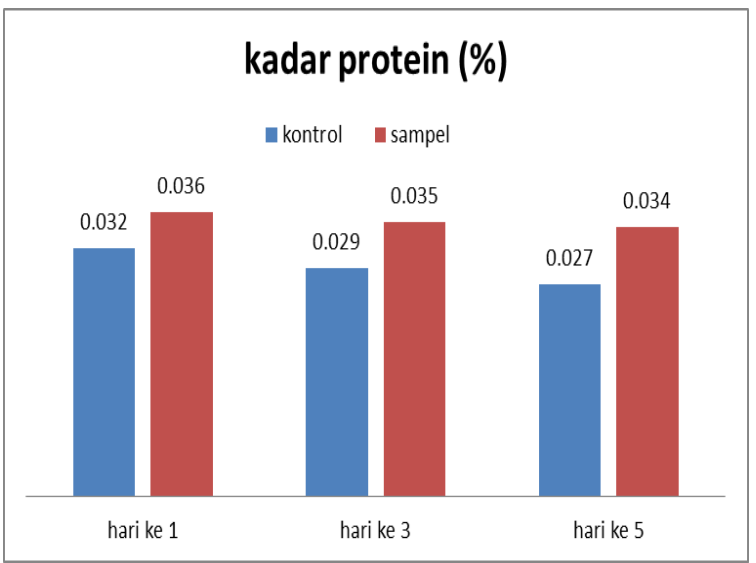

Gambar 4. Pengujian protein

Uji Mikrobiologi. Berdasarkan pengujian mikrobiologi, total koloni mikroba pada setiap sampel ditunjukkan pada tabel 1.

Tabel. 1 Total Koloni Mikroba

\begin{tabular}{cccc}
\hline & \multicolumn{3}{c}{ Pengamatan } \\
\cline { 2 - 4 } Sampel & Hari ke 1 & Hari ke 3 & Hari ke 5 \\
\hline A & $4,3 \times 10^{4}$ & $2,505 \times 10^{5}$ & $2,68 \times 10^{5}$ \\
\hline B & $2,5 \times 10^{3}$ & $1,81 \times 10^{5}$ & $2,33 \times 10^{5}$
\end{tabular}

Modifikasi Kitosan-Glukosa. Campuran kitosan-glukosa yang sudah dipanaskan memiliki warna yang berbeda dengan campuran kitosanglukosa sebelum dipanaskan. Hal ini dikarenakan campuran mengalami reaksi maillard. Reaksi maillard merupakan interaksi non enzimatis antara gula pereduksi dan asam amino, peptida, atau protein menghasilkan produk antara dan produk kecoklatan/melanoid. (Manzoco, 2003). Produk melanoid dijelaskan melalui jalur reaksi pemecahan senyawa metil dikarbonil (daridegradasi gula) dan menghasilkan flavor. (Shanta Laksmi, 2010). Flavour ini yang mengakibatkan campuran kitosan-glukosa menjadi beraroma harum.

Karakterisasi dengan IR. Pada pengujian IRterlihat bahwa kitosan mempunyai spektra kembar pada panjang gelombang 1542,15 cm-1 dan $1555,84 \mathrm{~cm}^{1}$ (lihat gambar 4.5). Hal ini menandakan kitosan memiliki gugus amina primer $\left(-\mathrm{NH}_{2}\right)$. Penelitian sebelumnya memberikan informasi bahwa jika kitosan dilarutkan dalam asam spektra kembar akan terbaca pada frekwensi $1654 \mathrm{~cm}^{1}$ dan $1594 \mathrm{~cm}^{-1}$. Spektra lain pada kitosan menunjukkan daerah dengan panjang gelombang $3370,11 \mathrm{~cm}^{-1}$. Panjang gelombang ini merupakan daerah dari gugus - $\mathrm{OH}$. Spektra gugus $\mathrm{OH}$ ini terbentuk karena kitosan dilarutkan dengan media air. Selain itu spektra juga terbaca pada panjang gelombang $1641,17 \mathrm{~cm}^{-1}$ yang menandakan adanya gugus karbonil $(\mathrm{C}=0)$. Gugus ini berasal dari asam asetat yang digunakan untuk melarutkan kitosan.

Pengujian IR terhadap campuran kitosanglukosa menunjukkan spektra yang mirip dengan spektra kitosan. Gambar 2 menunjukkan tidak adanya perbedaan yang signifikan antara spektra kitosan murni (bawah) dan campuran kitosanglukosa (atas). Keduanya memiliki spektra gugus $\mathrm{OH}$ dan gugus $\mathrm{C}=\mathrm{O}$. Hal ini menunjukkan bahwa reaksi yang berlangsung pada modifikasi kitosanglukosa merupakan reaksi maillard dan tidak disertai dengan perubahan gugus fungsi.Dimungkinkan antara kitosan dan glukosa hanya terjadi interaksi secara molekuler tanpa membentuk ikatan kuat.

Uji Organoleptik. Gambar 4 memberikan informasi bahwa haripertama menunjukkan ratarata dari 30 panelis memberikan nilai 2,10 untuk tampilan sampel kodeA dan 2,37 untuk tampilan sampel B. Hari ke 3, tampilan sampel A adalah 1,93 
dan sampel B adalah 2,70. Pengujian dihari kelima, tampilam sampel A diberikan nilai rata-rata 2,00 dan sampel B sebesar 2,57. Hal ini terlihat bahwa tampilan sampel A mengalami penurunan 0,17sedangkan sampel B mengalami kenaikan sebesar 0,33 dihari ketiga. Perubahan yang terjadi pada hari kelima adalah sampel 927 mengalami kenaikan sebesar 0,07 sedangkan sampel B mengalami penurunan sebesar 0,13.

Aroma sampel A adalah 2,57 dan sampel B adalah 3,13 pada hari pertama. Hari ketiga dan kelima sampel A berturu-turut mendapat nilai sebesar 2,63 dan 1,67 sedangkan sampel B berturut-turut sebesar 3,03 dan 1,87. Kenaikan terjadi dihari ketiga pada sampel 927 sebesar 0,06 sedangkan penurunan terjadi pada hari kelima sampel 927 dan 861 berturut-turut sebesar 0,96 dan 1,16 .

Warna sampel B dihari pertama, kedua, dan ketiga berturut-turut sebesar 2,17; 2,13; dan 2,23 sedangkan sampel A berturut-turut sebesar 2,77; 2,27; dan 2,50. Penilaian terhadap warna sampel mengalami penurunan dari hari kehari. Sampel B pada hari kedua mengalami penurunan 0,04 dan 0,1 dihari kelima. Penurunan nilai warna sampel A sebesar 0,5 dihari kedua dan 0,23 dihari $\mathrm{k}$ lima.

Rasa sampel A berturut-turut adalah 1,87; 2,37; dan 1,37 sedangkan sampel B berturut-turut sebesar 2,63; 2,33; dan 2,37. Rasa sampel A mengalami penurunan sebesar 1 di hari kelima dan kenaikan sebesar 0,5 di hari kedua. Sampel B menurun pada hari kedua sebesar 0,3 dan naik sebesar 0,04 pada hari kelima.

Berdasarkan hasil pengujian disimpulkan bahwa aspek penilaian yang dilakukan panelis terdapat kenaikan dan penurunan. Skor warna yang tertingg dari hari kesatu hingga hari kelima didapat oleh kode sampel 927. Hal ini dikarenakan warna ikan yang direndam dalam campuran kitosan-glukosa lebih berwarna kecoklatan dari pada ikan yang tidak direndam.

Pada hari ke 5 ikan yang tidak direndam campuran kitosan-glukosa berbau menyengat. Timbulnya bau merupakan indikator penurunan mutu bahan pangan karena aktivitas mikroba.
Mikroba dapat tumbuh di bahan pangan karena beberapa faktor. Faktor penting untuk pertumbuhan mikroba adalah persediaan zat gizi, suhu, aktivitas air, $\mathrm{pH}$, penyediaan oksigen dan bahan kimia (Supli Efendi, 2011). Penurunan mutu dalam ikan yang diteliti diduga disebabkan oleh aktivitas air dan bahan organik penyusun tubuh ikan.

Perendaman ikan bandeng sebelum dilunakkan memberikan manfaat pada tampilan, warna, aroma, dan rasa dari ikan tersebut. Hal ini ditunjukkan dengan hasil uji organoleptik pada kedua sampel tersebut.

Uji Protein. Kedua sampel mengalami penurunan protein setiap harinya (Gambar 3). Hari ketiga sampel ikan yang tidak direndam dengan campuran kitosan-glukosa menunjukkan penurunan sebesar 0,003 dari kadar 0,032\% menjadi $0,029 \%$. Sedangkan pada hari kelima mengalami penurunan sebesar 0,002 menjadi $0,027 \%$. Angka penurunan protein yang lebih sedikit terjadi pada sampel ikan yang telah direndam dengan campuran kitosan-glukosa. Hari ketiga terjadi penurunan sebesar 0,001 dari 0,036 menjadi 0,035. Selanjutnya dihari kelima, penurunan kadar protein sebesar 0,001 dari 0,035\% menjadi $0,034 \%$.

Penurunan protein disebabkan oleh kamampuan mikroba yang dapat menghasilkan enzim proteolitik yang dapat memecah molekul protein dalam bahan pangan (Maulana, 2012). Protein dipecah menjadi asam amino dan berikutnya menjadi senyawa yang mengandung sufur dan nitrogen dengan berat molekul rendah yang menyebabkan bau busuk (Theresia, 2007).

Kandungan protein diawal pun terlihat bahwa sampel ikan yang telah direndam dalam campuran kitosan-glukosa lebih tinggi dari sampel ikan yang tidak mengalami perendaman dengan campuran kitosan-glukosa. Tingginya kadar protein ikan yang mengalami proses perendaman dengan campuran kitosan-glukosa dikarenakan adanya tambahan gugus $\mathrm{NH}_{2}$ dari kitosan.

Kelemahan reaksi protein dengan biuret adalah jika sampel protein mengandung senyawa lain yang mempunyai ikatan $-\mathrm{CH}_{2} \mathrm{NH}_{2}$, - 
$\mathrm{CHNHNNH}_{2}$, dan $-\mathrm{CSNH}_{2}$ maka laruan biuret akan memberikan reaksi positif (Abdul Rohman, 2007). Oleh sebab itu adanya gugus $\mathrm{NH}_{2}$ dari kitosan akan bereaksi positif dengan laruta biuret sehingga pembacaan kandungan kadar protein menjadi lebih tinggi.

Uji Mikrobiologi. Berdasarkan data percobaan uji mikrobiologi pada hari pertama, sampel ikan yang tidak direndam dalam campuran kitosan-glukosa memiliki koloni sebanyak 4,3 x $10^{4} \mathrm{CFU} /$ gram. Hari ketiga dan kelima berturutturut mengalami kenaikan menjadi 2,505 x $10^{5}$ dan $2,68 \times 10^{5}$. Sampel ikan yang direndam dalam campuran kitosan-glukosa memiliki koloni sebanyak 2,5 x $10^{3} \mathrm{CFU} /$ gram dihari pertama. Hari ketiga dan kelima menunjukkan kenaikan menjadi $1,81 \times 10^{5} \mathrm{CFU} /$ gram dan 2,33 x $10^{5} \mathrm{CFU} /$ gram.

Kenaikan jumlah koloni pada sampel ikan yang tidak direndam dalam campuran kitosanglukosa dihari ketiga dan kelima berturut-turut sebesar 2,07 x $10^{2}$ dan $1,75 \times 10^{1}$. Sampel ikan yang direndam dalam campuran kitosan-glukosa dihari ketiga dan kelima berturut-turut sebesar $1,78 \times 10^{2}$ dan $5,2 \times 10^{1}$. Hasil pengujian mikrobiologi menunjukkan data yang kurang signifikan karena penurunan jumlah koloni. mikroba pada ikan yang direndam campuran kitosan-glukosa dihari yang kelima lebih tinggi dibanding sampel lain.

Menurut SNI 3925:2008 dijelaskan jumlah maksimal kandungan TPC yaitu 1 x $10^{6} \mathrm{CFU} /$ gram. Hasil uji mikrobiologi dari sampel menunjukkan bahwa dari hari kesatu hingga hari kelima pertumbuhan koloni mikroba semakin banyak. Selain ada faktor yang mempengaruhi pertumbuhan mikroba seperti pembahasan sebelumnya (lihat pembahasan uji organoleptik.)pertumbuhan mikroba dapat dijelaskan dengan gambar sebagai berikut.

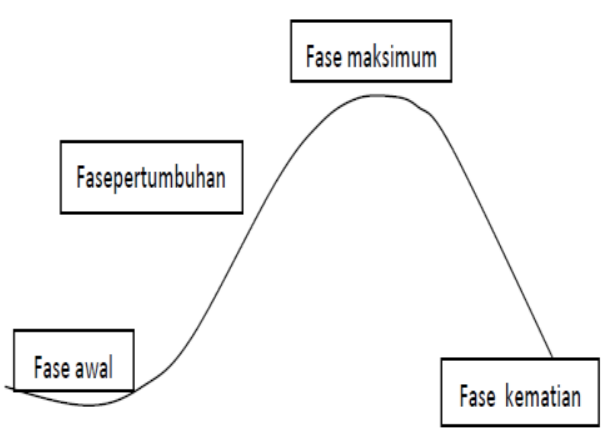

Gambar 5. Fase pertumbuhan Mikrobia

Pertumbuhan mikroba (gambar 5) bermula dari fase awal kemudian menuju fase pertumbuhan naik ataupertumbuhan mikroba yang cepat. Pada fase maksimal merupakan fase titik balik pertumbuhan mikroba sebelum turun ke fase kematian. (Supli Efendi, 2011).Penelitian yang dibatasi waktu hingga 5 hari ini menunjukkan nilai total koloni mikroba masih dibawah batas maksimum yang ditetapkan SNI. Hasil koloni mikroba pada ikan yang direndam dalam campuran kitosan-glukosa lebih sedikit dibanding ikan yang tidak mengalami perendaman. Hal ini menunjukkan bahwa campuran kitosan-glukosa mempunyai kemampuan sebagai anti mikroba.

Hasil uji mikrobiologi ini menguatkan pernyataan bahwa modifakasi kitosan untuk menghasilkan produk yang lebih baik.Modifikasi kitosan dapat memperbaiki sifat tanpa mempengaruhi kemampuan sebagai anti mikroba.

Secara umum data pengujian merupakan data yang saling berkaitan. Jumlah mikroba sangat mempengaruhi sifat fisik maupun kimia dari bahan pangan. Mikroba tumbuh jika didukung dengan kondisi bahan pangan (substrat). Substrat yang terdiri dari bahan-bahan organik merupakan suplai nutrisi untuk mikroba sehingga mikroba akan mampu hidup dan berkembang. Mikroba mempunyai kemampuan untuk memecah rantai panjang protein sehingga menjadi senyawa yang lebih sederhana. Perubahan inilah yang menjadikan bahan pangan berbau busuk. Penurunan mutu pangan yang ditandai aroma busuk akan mempengaruhi nilai organoleptik terhadap bahan pangan tersebut. 
Berdasarkan data hasil penelitian, campuran kitosan-glukosa mampu diaplikasikan di bahan pangan. Kitosan mempunyai kemampuan sebagai anti mikroba. Glukosa yang digunakan untuk memperbaiki fungsi kitosan memberikan kontribusi untuk membentuk flavourpada bahan pangan. Campuran keduanya mampu menjaga mutu makanan selama penyimpanan.

Ikan bandeng yang digunakan sebagai sampel pengujian menunjukkan perbedaan secara fisik maupun kimia. Ikan bandeng yang telah di rendam dalam campuran kitosan-glukosa memberikan perbedaan dalam berbagai aspek pengujian organoleptik. Pengujian protein menunjukkan ikan yang direndam campuran kitosan-glukosa mempunyai kadar protein lebih tinggi walaupun terdapat penuruan setiap harinya. Kadar protein yang lebih tinggi disebabkan karena bertambahnya gugus $\mathrm{NH}_{2}$ yang berasal dari kitosan pada saat proses perendaman. Penurunan kadar protein terjadi akibat adanya aktifitas mikroorganisme yang merusak struktur dari protein. Pengujian mikrobiologi menunjukkan bahwa pertumbuhan mikroba lebih sedikit dibanding dengan ikan yang tidak mengalami perendaman.

\section{Kesimpulan}

Aktifitas modifikasi kitosan-glukosa yang diaplikasikan untuk pengawet ikan bandeng duri lunak terlihat bahwa secara fisik pada hari ke 5 ikan bandeng yang dilapisi kitosan glukosa mempunyai nilai tampilan, warna, aroma, rasa sebesar 2,57;1,87;2,23;2,37. Nilai ini lebih besar dibandingkan ikan yang tidak dilapisi kitosanglukosa sebesar 2;1,67;2,5;1,37. Kadar protein pada hari ke 5 memiliki perbedaan sebesar 0,0075\%. Uji mikrobiologi di hari ke 5 terlihat adanya perbedaan kandungan mikrobiologi sebesar $1,37 \times 10^{6} \mathrm{CFU}$. Pengujian dengan spektro infra merah (IR) menunjukkan tidak adanya perubahan gugus antara kitosan murni dan modifikasi kitosan-glukosa.

\section{Daftar Pustaka}

Abdulmumeen, Hamid dkk, Food: Its preservatives, additives, applications, Nigeria: International Journal of Chemical and Biochemical Sciences, 2012

Alsuhendra, Bahan Toksik dalam Makanan, Bandung: PT Remaja Rosdakarya, 2013, Babiker dalam Kanatt, Chitosan glucose complex - A novel food preservative, India: Elsevier Journal, 2007

Bastaman, 1989 dalam Falahudin, An'im, Kitosan Sebagai Edible Coating Pada Otak-Otak Bandeng (Chanos chanos Forskal) yang Dikemas Vakum [skripsi]. Bogor: Fakultas kelautan dan Ilmu Perikanan IPB, 2009

Bintang, Maria, Biokimia Teknik Penelitian, Jakarta: Erlangga, 2010

Chang, Raymond, Kimia Dasar konsep-Konsep Inti, Jakarta: Erlangga, 2004

Darmawan, Deni, Metode Penelitian Kuantitatif, Bandung: PT Rosdakarya, 2013

Falahudin, An'im, Kitosan Sebagai Edible Coating Pada Otak-Otak Bandeng (Chanos chanos Forskal) yang Dikemas Vakum [skripsi], IPB, 2009

Fessenden \& Fessenden, Kimia Organik Jilid I, Jakarta: Erlangga, 2003

Hadwiger dan Adams,1978; Hadwiger dan Loschake, 1981 diacu dalam Hardjito, 2006, dalam Ira Wiraswati. Pemanfaatan Kargenan Dan Kitosan Dalam Pembuatan Bakso Ikan Kurisi (Nemipterus nematophorus) Pada Penyimpanan Suhu Dingin dan Beku. Bogor: Fak Perikanan dan Ilmu kelauan IPB, 2008

Hargono dkk, Pembuatan Kitosan dari Limbah Cangkang Udang serta Aplikasinya dalam Mereduksi Kolesterol Lemak Kambing, Semarang: Jurnal Reaktor Undip vo 12 No 1, 2008

Irawan , Agus, Pengolahan Hasil Perikanan Home Industri, Solo: CV. Aneka, 1995 
Johnson, Laboratory Eksperiments in Microbiology, Pearson Education, 2013

Kanatt dkk, 2007 dalam Selly Ratnasari dkk. Aktivitas Antioksidan Kitosan Kompleks Monosakarida. Palembang: Fishitech Journal Vol II Teknologi Hasil Perikanan Universitas Sriwijaya, 2013

Kanatt, Chitosan glucose complex - A novel food preservative, India: Elsevier Journal, 2007

Khopkar, Konsep Dasar Kimia Analitik, Jakarta: UI Press, 2007

Lakshmi, Shanta,Chitosan-Glucose Conjugates: Influence of Extent of Maillard Reaction on Antioxidant Properties, Australia: Journal Agricultural and chemistry food, 2010

Manzocco et all dalam Phisut dan Jirapo, Characteristics and antioxidant activity of Maillard reaction products derived from chitosan-sugar solution, Thailand: International Food Research Journal, 2003

Maulana, dkk, Pembuatan Kecap dari Ikan Gabus Secara Hidrolisis Enzimatis Menggunakan Sari Nanas. Semarang: Journal Teknologi Kimia dan Industri Volume 1, 2012

Muchtadi, Dedy,Teknik Evaluasi nilai Gizi protein, Bandung: Alfabeta, 2010

Muzzarelli dkk, 1997; Shahidi dkk, 1999 dalam Emma Rochima, Karakterisasi Kitin dan Kitosan Asal Limbah Rajungan Cirebon Jawa Barat. Bandung: Universitas Padjajaran, 2010

Nielsen, Suzanne, Food Analysis Fourth Edition, USA: Springer, 2009

Palupi, N.S dkk, Modul E-Learning Pengaruh Pengolahan Terhadap Nilai Gizi Pangan, Bogor: Dep. Ilmu dan Teknologi Pangan, 2007

Ratnasari, Selly dkk. Aktivitas Antioksidan Kitosan Kompleks Monosakarida. Palembang: Fishitech Journal Vol II Teknologi Hasil Perikanan Universitas Sriwijaya, 2013
Rinaudo, Marguerite, Chitin and chitosan: Properties and applications, France: Elsevier Journal, 2006

Rohman, Abdul, Analisis Komponen Makanan, Yogyakarta: Graha Ilmu, 2013

Sri Suharni, Theresia, Mikrobiologi Umum, Yogya: Univ. Atma Jaya, 2007

Sumantri , Abdul Rohman, Analisa Makanan, Yogyakarta: UGM Press, 2007

Susanto, Eko, Pengolahan Bandeng Duri Lunak, Disampaikan pada program penyuluhan bagi masyarakat pesisir di kabupaten Batang tanggal 27 - 28 Juli 2010, Staf pengajar Program Studi Teknologi Hasil Perikanan, Jurusan Perikanan, Fakultas Perikanan dan Ilmu Kelautan Universitas Diponegoro Semarang

Susiwi, Penilaian Organoleptik "Handout", Bandung: Pendidikan Kimia UPI, 2009

Swastawati , Frontea dkk, Pemanfaatan Limbah Kulit Udang Menjadi Edible Coating Untuk Mengurangi Pencemaran Lingkungan, Semarang: Jurusan Perikanan Universitas Diponegoro, 2008

Wang, Qin, Recent Advances of Chitosan and Its Derivatives for Novel Applications in Food Science., Journal of Food Processing \& Beverages vol 1, Department of Nutrition and Food Science, University of Maryland, USA, 2013,

Wisnu Cahyadi, Bahan Tambahan Pangan, Jakarta: Bumi Aksara, 2008. 